For Debate ...

\title{
Are we failing our teenagers? Value of a family planning service for teenagers within the sexually transmitted disease clinic
}

\author{
JEAN M TOBIN, R BASU ROY
}

\begin{abstract}
Out of 100 teenage girls attending a sexually transmitted disease clinic for the first time, 77 were found to be using a reliable method of contraception and had similar characteristics to teenage girls attending a family planning clinic. The $\mathbf{2 3}$ girls not using any reliable contraception exhibited-a different pattern of sexual behaviour and were at high risk of unplanned pregnancy. Subsequently, another group of 23 girls not using contraception when seen at the sexually transmitted disease clinic were actively encouraged to attend a family planning clinic. Their risk of unplanned pregnancy was much reduced, although their pattern of sexual activity was unchanged.

Ready availability of contraceptive advice for unprotected teenagers in sexually transmitted disease clinics would reduce their high risk of unplanned pregnancy.
\end{abstract}

\section{Introduction}

Jamieson et al stated that, apart from sexually transmitted disease, problems of teenage sexuality stem from pregnancy rather than from sexual behaviour.' Certainly venereal disease is a considerable problem, one third of all recorded cases of gonorrhoea in women in Britain in 1981 occurring in teenagers. ${ }^{2}$

In 1983 the figure for terminations of pregnancy in teenagers in England and Wales was $41034,{ }^{3}$ and that for live births (30 400) to unmarried women in this age group represented $56 \%$ of all live births to teenage women. ${ }^{4}$ These figures have risen steadily over the past decade.

We considered that attendance at a sexually transmitted disease clinic of teenage girls not using a reliable method of contraception might be the only opportunity presented for offering contraceptive advice. Therefore, we decided to conduct a study to determine the role of family planning for teenagers in the clinic and to consider how, if effective, the service could be extended to other clinics.

\section{Patients and methods}

Patients included in the study fell into four groups. One hundred new teenage patients seen consecutively in the sexually transmitted disease clinic were divided into two groups based on the use or otherwise of a reliable method of contraception. Seventy seven were using reliable contraception (group 1) and 23 were not (group 2). At their first consulta-

Department of Genitourinary Medicine, St Mary's Hospital, Portsmouth JEAN M TOBIN, MRCOG, consultant

Department of Genitourinary Medicine, Royal Victoria Hospital, Bournemouth R BASU ROY, FRCS, consultant

Correspondence to: Dr Jean M Tobin. tion all patients in the study were asked about their age at first sexual intercourse, their total number of partners since then, and about their knowledge and use of contraceptives. Those girls not using any reliable method of contraception were asked additionally why this was so and whether they would have liked a method prescribed on this occasion if such a service had been available. They were given information about the family planning clinic held for two hours each week in the sexually, transmitted disease clinic by a visiting doctor and nurse, about local family planning clinics in their home and work areas, and especially about the nearby youth advisory clinic. Appointments were made on their behalf if requested.

These 100 patients were followed up for an average of 26.5 months and during subsequent visits to the clinic any contraceptive use, pregnancies, or change of sexual partner was noted. For those who did not reattend information was obtained from the family planning clinic and hospital records to which access was granted or by contacting the patient direct.

Concurrently, for comparison, 100 teenage girls presenting consecutively for the first time at a routine family planning clinic (group 3 ) were similarly questioned and followed up for an average of 23 months.

Subsequently a separate group of 23 teenage girls (group 4) not using any reliable contraception when first seen at the sexually transmitted disease clinic were actively encouraged to attend family planning clinic sessions held by one of us (JMT) elsewhere. The follow up period for this group averaged 26 months.

\section{Results}

FIRST ATTENDANCE (GROUPS 1 TO 3)

Over $95 \%$ of all the patients studied were unmarried. Those in group 1 had an average age of 18 years 4 months (range 15 years 7 months to 19 years 11 months), those in group 2 an average age of 17 years 1 month (range 12 years 8 months to 19 years 8 months), and those in group 3 an average age of 17 years 7 months (range 14 years 2 months to 19 years 11 months). Table I gives their age at first sexual intercourse, number of previous pregnancies, number with gonorrhoea diagnosed in the clinic, and employment state. Table II shows the number of previous sexual partners had by the patients in each group.

Contraceptive use- Of the 23 girls in group 2, of whom two were pregnant, 14 were not using any contraception and nine were using an unreliable method. Of the 100 girls attending the family planning clinic (group 3), 62 were using a reliable method and 16 (four of whom were pregnant when first seen) were not. The remaining 22 had not had sexual intercourse.

Knowledge of methods of contraception-Judged on their knowledge of types of contraception available, only three girls in group $2(13 \%)$ and 11 in group 3 (11\%) were considered to be badly informed, although six of the

TABLE I-Details of patients at first attendance at sexually transmitted disease clinic or family planning clinic (group 3)

\begin{tabular}{llccc}
\hline \multicolumn{1}{c}{ Group } & $\begin{array}{c}\text { Average age at first } \\
\text { sexual intercourse }\end{array}$ & $\begin{array}{c}\text { No (\%) with } \\
\text { previous } \\
\text { pregnancies }\end{array}$ & $\begin{array}{c}\text { No (\%) with } \\
\text { gonornoea } \\
\text { diagnosed }\end{array}$ & $\begin{array}{c}\text { No (\%) } \\
\text { unemployed }\end{array}$ \\
\hline $1(n=77)$ & 17 years 1 month & $9(12)^{\star}$ & $10(13)$ & $10(13)$ \\
$2(n=23)$ & 15 years 11 months & $5(22)$ & $9(39)$ & $9(39)$ \\
$3(n=100)$ & 16 years 9 months & $5(5)$ & $-6(26)$ & $\begin{array}{r}10(10) \\
8(35)\end{array}$ \\
$4(n=23)$ & 16 years 2 months & $5(22)$ & $6(2)$ & \\
\hline
\end{tabular}

*Two were planned pregnancies. 
girls in group $2(26 \%)$ did not know where contraceptives could be obtained locally.

Reasons for non-use of contraception among attenders at sexually transmitted disease clinic-Multiple, usually vague reasons were offered for having not used contraception, but none of the girls admitted to wanting a pregnancy. All would have preferred an oral contraceptive had this been available on this first visit. Only one under 16 year old expressed concern about confidentiality if she attended a family planning clinic.

TABLE II-Numbers of previous sexual partmers had by patients attending sexually transmitted disease clinic or family planning clinic (group 3). Data expressed as number (percentage) of patients in each group

\begin{tabular}{ccccc}
\hline $\begin{array}{c}\text { No of } \\
\text { partners }\end{array}$ & $\begin{array}{c}\text { Group 1 } \\
(\mathbf{n}=77)\end{array}$ & $\begin{array}{c}\text { Group 2 } \\
(\mathbf{n}=23)\end{array}$ & $\begin{array}{c}\text { Group } 3 \\
(\mathbf{n}=100)\end{array}$ & $\begin{array}{c}\text { Group 4 } \\
(\mathbf{n}=23)\end{array}$ \\
\hline 0 & 0 & 0 & $22(22)$ & 0 \\
1 & $31(40)$ & $5(22)$ & $56(56)$ & $7(30)$ \\
2 & $22(29)$ & $1(4)$ & $11(11)$ & $4(17)$ \\
3 & $16(21)$ & $9(39)$ & $4(4)$ & $8(35)$ \\
$\geqslant 4$ & $8(10)$ & $8(35)$ & $7(7)$ & $4(17)$ \\
\hline
\end{tabular}

\section{FOLLOW UP (GROUPS 1 TO 3)}

Of the girls in group 2, only four subsequently attended a family planning clinic, all of whom selected oral contraceptives. At the end of the study $65(84 \%)$ of the 77 girls in group 1 were still using their original method of contraception, as were 89 of the 100 girls in group 3 . In both groups over $85 \%$ were pill users.

Table III shows the numbers of subsequent pregnancies among the girls, numbers remaining with the same sexual partners, and numbers reattending the clinic with gonorrhoea.

TABLE III-Follow up data on all four groups

\begin{tabular}{|c|c|c|c|c|}
\hline Group & $\begin{array}{l}\text { No (\%) } \\
\text { with } \\
\text { subsequent } \\
\text { pregnancies }\end{array}$ & $\begin{array}{l}\text { No }(\%) \\
\text { remaining } \\
\text { with same } \\
\text { pertners }\end{array}$ & $\begin{array}{l}\text { No (\%) } \\
\text { reattending } \\
\text { sexually transmitted } \\
\text { disease clinic }\end{array}$ & $\begin{array}{l}\text { No (\%) } \\
\text { with } \\
\text { gonorrhoea } \\
\text { diagnosed }\end{array}$ \\
\hline $\begin{array}{l}1(n=77) \\
2(n=23) \\
3(n=100) \\
4(n=23)\end{array}$ & $\begin{array}{l}7 \text { (9); } 4 \text { planned } \\
20 \text { in } 13 \text { girls ( } 57) ; 5 \text { planned } \\
5 \text { (5); } 3 \text { planned } \\
2 \text { (9); } 1 \text { planned }\end{array}$ & $\begin{array}{l}42(55) \\
5(22) \\
70(70) \\
7(30)\end{array}$ & $\begin{array}{l}30(39) \\
7(30) \\
6(26)\end{array}$ & $\begin{array}{l}4(5) \\
5(22) \\
4(17)\end{array}$ \\
\hline
\end{tabular}

\section{GROUP 4}

The 23 patients in group 4 (average age 17 years 9 months; range 13 years 2 months to 19 years 11 months) closely matched those in group 2 (tables I and II). Only three (13\%) had a poor knowledge of contraception, and all wanted to use a method when asked. Later one of these changed her mind and was lost to follow up.

Eleven of the remaining 22 girls attended the family planning clinic for their first arranged appointment. Those who failed to attend were contacted and offered further appointments, seven also being offered transport to the clinic (family planning clinic domiciliary service). Eventually, all 22 attended. Seventeen girls (77\%) chose oral contraception and, with one exception, all persisted with their original chosen method. After the first few visits to the clinic patients were encouraged to transfer to geographically more convenient clinics, and 17 did so.

\section{Discussion}

We were encouraged to find that $77 \%$ of teenagers attending the sexually transmitted disease clinic were using a reliable method of contraception. Those not using any reliable method were younger but had been sexually active for as long or longer than the other groups. Their subsequent lack of contraceptive use shows that their young age was not a factor at the time they were first seen. There is evidence that one in eight girls under 16 is sexually active in Britain ${ }^{5}$ and that the age at first sexual intercourse has been decreasing, especially since $1970 .^{6}$ At the same time, however, there has been an upward trend in the number of girls attending a family planning clinic before starting intercourse, quoted figures being very similar to those in this study. ${ }^{17}$ It has been estimated that among teenagers a gap of six months between first intercourse and use of contraception is common, ${ }^{8}$ with an average of nine months before they attend a family planning clinic. ${ }^{9}$ Even though they were younger the 23 non-contraceptive users had a much higher percentage of previous pregnancies, and American figures have shown that half of all first premarital teenage pregnancies occur within six months of first intercourse because no contraception has been used. ${ }^{10}$

Surprisingly, lack of knowledge about contraception did not seem to be related to non-use, although non-users seemed less motivated to find an available source. The ambivalence shown by non-users has been well described in other surveys." Possibly education should be directed towards the need to use a reliable method on every occasion, as it appears that familiarity with methods available does not guarantee their regular use..$^{12} 13$

With their history of more sexual partners, we were surprised that the rate for reattendance at the sexually transmitted disease clinic among non-contraceptive users was not higher, but when they did attend they were several times more likely to have gonorrhoea. The high unplanned pregnancy rate among noncontraceptive users (group 2) was expected, however; nevertheless, all of the pregnancy figures may be an underestimate, as it is possible that some girls arranged a termination outside the area or did not admit to an unplanned pregnancy, though this would not affect the overall picture. Sadly, by the end of the survey one girl who had suffered from gonorrhoea twice was being treated for infertility.

It became apparent in this study that the girls attending the sexually transmitted disease clinic who were using contraception and those attending a family planning clinic were similar both in their pattern of sexual activity and in their employment state. The non-contraceptive users were equally knowledgeable but not motivated towards contraception, often despite previous unwanted pregnancies. Although none wanted to conceive (and over $80 \%$ of teenage pregnancies may be unintentional ${ }^{8}$ ) and all would have liked the effortless availability of contraceptives-especially the pill-from the clinic, their enthusiasm fell short of attending a family planning clinic even when a date had been agreed.

Because of this apparent uninterest, the high number of girls in group 4 who were eventually persuaded to seek family planning advice was unexpected and the high continuation rate even more so. This was as good as in group 3, and in both groups the rates were higher than in many surveys, where a default rate of $20 \%$ is common. ${ }^{7}$ A reason for this high attendance may have been that the girls already knew the person they would see from the sexually transmitted disease clinic, but whatever the incentive to enrol they rapidly became confident attenders, happy to transfer to a more convenient clinic and not dependent on the individual member of staff.

The pregnancy rate dropped steeply, confirming the calculation that one live birth or 2.8 pregnancies are avoided every year for each 10 teenagers attending a family planning clinic. ${ }^{14}$ Interestingly, this more responsible attitude to contraception did not alter other aspects of their sexual activity as compared with the original group of non-users (group 2), as their subsequent attendance at the sexually transmitted disease clinic, risk of gonorrhoea, and inclination for multiple partners were similar. The high use of oral contraceptives in this study was consistent with the findings of other workers. ${ }^{17}$

If the main problems of teenage sexuality are venereal disease and pregnancy then we are providing a good service within clinics for the treatment of the first while missing an opportunity in some cases to prevent the second. It seems inadequate just to provide a family planning service within the department for a short time each week, but contraceptive counselling within the clinic for this relatively small number of teenagers at risk would be highly cost effective in preventing pregnancy and its associated problems. This service could be provided by a nurse, trained and actively engaged in family planning work, being available during clinic hours to talk to these patients and follow them through to attendance at a family planning clinic. This attendance should be as rapid and effortless as possible while motivation remains high.

This survey shows the results of not pursuing the problem of 
contraception in teenagers. The prevention of pregnancies possible in this high risk group, however, would amply justify the increased time and effort. If those of us working with this group are not prepared to offer contraceptive advice and help when it is needed, then we are indeed failing our teenagers.

Thanks are due to Mrs G M Buick, Fareham family planning clinic secretary, for her help with the records and Dr M Laxton for allowing access to Southampton family planning clinic records.

\section{References}

1 Jamieson L, Bury JK, McGlew T. Young persons' contraceptive clinic 1975 to 1980: patterns of use. Health Bull (Edinb) 1983;41:68-77.

2 Chief Medical Officer, DHSS. Sexually transmitted diseases; extract from annual report for 1982. Br f Vener Dis 1984;60:199-203.
3 Office of Population Censuses and Surveys. Legal abortions 1983. OPCS monitor. London: HMSO, 1984. (AB 84/6.)

4 Office of Population Censuses and Surveys. Live births during 1983 by mother's age, legitimacy and birth order. OPCS monitor. London: HMSO, 1984. (FMI 84/4.)

Guillebaud J. Minimising the hazards of contraception in the under-16s. Modern Medicin 1980;25:38-40.

First coitus. British Joumal of Sexual Medicine 1982;9:31-3.

Harrison N, Bury JK. A young people's advisory service. Health Bull (Edinb) 1982;4:133-9. Caris

Jones JB, Namerow PB, Philliber S. Adolescents' use of a hospital based contraceptive program.

10 Zabin LS, Kantner JF, Zalnik M. The risk of adolescent pregnancy in the first months of intercourse. Fam Plann Perspect 1979;11:215.

1 Zabin LS, Clark SD. Why they delay-a study of teenage family planning clinic patients. Fam

Plann Perspect 1981;13:205-7,211-7.
12 Zelnik M, Shah FK. First intercourse among young Americans. Fam Plann Perspect 1983;15:

64-70. $M$, Young JK. Sex education and its association with teenage sexual activity, pregnancy and contraceptive use. Fam Plann Perspect 1982;14:117-9,123-6.

Planning clinic programs on

Accepted 19 October 1984)

\section{Clinical Algorithm}

\section{Hypercalcaemia}

\section{J JAMIESON}

Four key questions are central to the assessment of the apparently hypercalcaemic patient. As assessment evolves they arise in the following order: Is this true hypercalcaemia? Is urgent treatment required? What is the cause? What treatment, if any, is required electively?

In deciding whether a single estimation of serum calcium concentration reflects true sustained hypercalcaemia, three factors should be considered: firstly, a normal person may have a high serum calcium concentration on a given occasion (compared with his laboratory's reference range) solely as a chance occurrence; secondly, measurements of serum calcium concentration generally include a protein bound fraction of $40-45 \%$, of which about $90 \%$ is bound to albumin. To assess whether measured serum calcium includes a physiologically appropriate free calcium concentration a correction must be made for bound calcium. Estimates of average calcium-albumin binding derived from regression equations are widely used, and popular correction factors are $0.025 \mathrm{mmol}(1 \mathrm{mg})$ calcium $/ \mathrm{g}$ albumin and $0.1 \mathrm{mmol}(4 \mathrm{mg})$ calcium $/ 6 \mathrm{~g}$ albumin. In either case an appropriate amount is subtracted from or added to total calcium according to the amount by which the serum albumin concentration exceeds or falls short of a normal concentration (usually around $40 \mathrm{~g} / \mathrm{l}$ ): For example, using the first of these correction factors, a patient whose serum calcium concentration is $2.80 \mathrm{mmol} / \mathrm{l}(11.2 \mathrm{mg} / 100 \mathrm{ml})$ and serum albumin concentration is $50 \mathrm{~g} / \mathrm{dl}$ has a corrected serum calcium concentration of $2.55 \mathrm{mmol} / \mathrm{l}$ $(10.2 \mathrm{mg} / 100 \mathrm{ml})-2: 80-((50-40) \times 0.025)$. A patient whose serum calcium concentration is $2.00 \mathrm{mmol} / 1(8 \mathrm{mg} / 100 \mathrm{ml})$ and serum albumin concentration is $30 \mathrm{~g} / \mathrm{dl}$ has a corrected calcium concentration of $2.25 \mathrm{mmol} / 1(9 \mathrm{mg} / 100 \mathrm{ml})-2 \cdot 00+((40-30) \times 0.025)$.

Department of Therapeutics and Clinical Pharmacology, Royal Infirmary, Aberdeen AB9 2ZB

M J JAMIESON, MRCP, lecturer

Correspondence to: Division of Clinical Pharmacology, University of Texas Health Service Center, San Antonio, Texas, 78284, USA.
The application of average correction values is somewhat empirical as, strictly, they should be applied only to members of the populations from which they are derived and, more particularly, as individual variation in calcium-albumin binding appears to be considerable. Most studies, nevertheless, have been able to assign a diagnosis in most cases without defining individual regression coefficients. Thirdly, sampling variables should be excluded; serum calcium concentrations in samples taken standing, after venous occlusion, and postprandially may exceed the supine, tourniquet free, and fasting values by as much as $0.25 \mathrm{mmol} / 1(1 \mathrm{mg} / 100 \mathrm{ml})$ in each case.

\begin{tabular}{ll}
$\begin{array}{l}\text { TABLE I-Causes of hypercalcaemia. Figures in parentheses represent } \\
\text { typical incidences in hospital series }\end{array}$ \\
\hline \multicolumn{1}{c}{ Type of cause } & \multicolumn{1}{c}{ Cause } \\
\hline Common & $\begin{array}{l}\text { Malignancy (55\%) } \\
\text { Hyperparathyroidism (35\%) } \\
\text { Renal dialysis and transplantation } \\
\text { Thyrotoxicosis } \\
\text { Sarcoidosis } \\
\text { Vitamin D excess } \\
\text { Mare (less than 1\%) } \\
\text { Thilk-alkali syndrome } \\
\text { Thiazide diuretics } \\
\text { Lithium } \\
\begin{array}{l}\text { Familial hypocalciuric hypercalcaemia } \\
\text { Immobilisation (eg in Paget's disease) }\end{array} \\
\begin{array}{l}\text { Addison's disease } \\
\text { Acromegaly }\end{array} \\
\text { Phaeochromocytoma } \\
\text { Cystic breast disease } \\
\text { Coccidioidomycosis } \\
\text { Vipoma (vasoactive intestinal polypeptide } \\
\text { tumour) }\end{array}$ \\
\hline
\end{tabular}

\section{Causes}

Table I gives a list of causes. In an unselected population the commonest cause will probably be primary hyperparathyroidism; in hospital series malignancy is commoner. Together these account for about $90 \%$ of cases. Other causes are individually uncommon and when present may coexist with hyperparathyroidism. 